\title{
A K+F STÚDIÓ „HÖLGYEK A TUDOMÁNYBAN” CÍMÜ TEHETSÉGGONDOZÓ PROGRAMJA
}

\author{
Szerző: \\ Mező Katalin (PhD) \\ $\mathrm{K}+\mathrm{F}$ Stúdió Kft. \\ Mező Ferenc (PhD) \\ $\mathrm{K}+\mathrm{F}$ Stúdió Kft.
}

Első szerző e-mail címe:

ferenc.mezo1@gmail.com

\section{Lektorok:}

Borbélyné Bacsó Viktória (PhD) Medgyessy Ferenc Gimnázium és Művészeti Szakgimnázium

Ildikó Psenáková

Trnava University in Trnava

(Szlovákia)

...és további két anonim lektor

\begin{abstract}
Absztrakt
A „Hölgyek a tudományban” a K+F Stúdió Kft. egyik tehetségfejlesztő programja. E program célja a középiskolás hölgyek tehetségfejlesztése a tudomány területén. A program eredményei és termékei: a résztvevők cikkei, konferencia-előadások, filmek és egy könyv errôl a programról.
\end{abstract}

Kulcsfogalmak: tehetség, innováció

Diszciplinák: pedagógia, pszichológia

\section{Abstract}

'LADIES IN SCIENCE'

ENTITLED TALENT DEVELOPMENT PROGRAM OF K+F STÚDIÓ

The 'Ladies in Science' is one of the talent development program of $K+F$ Stúdio Kft. The purpose of this program is the talent development of secondary school women in the field of sciences. Results and products of the program are: the participants' articles, conference presentations, films and a book about this program.

Keywords: talent, innovation

Disciplines: pedagogy, psychology

Mező Katalin és Mező Ferenc (2020): A K+F Stúdió „Hölgyek a tudományban” című tehetséggondozó programja. OxIPO - interdiszciplináris tudományos folyóirat, 2020/1, 95-99. doi: 10.35405/OXIPO.2020.1.95 
A Nemzeti Tehetség Program támogatásával kerül megvalósításra a $\mathrm{K}+\mathrm{F}$ Stúdió Kft. „Hölgyek a tudományban” című tehetséggondozó programja a 2019/2020 tanévben. A program célja, hogy a résztvevő hölgyeket (akik a debreceni Medgyessy Ferenc Középiskolában és Művészeti Gimnáziumban folytatják tanulmányaikat) érzékenyítse a tudományos kutatással, a kutatói pályával kapcsolatban. A $\mathrm{K}+\mathrm{F}$ Stúdió Kft. részéről dr. Mező Katalin, a gimnázium részéről Kiss Papp Csilla koordinálta a programot, s a kerekasztalbeszélgetéseken résztvevők között üdvözölhettük a gimnázium tanárai közül Borbélyné dr. Bacsó Viktóriát (fizika), illetve drs. Jász Erzsébetet (földrajz) is.

\section{1. ábra: készülnek a tanulmányok (forrás: a}

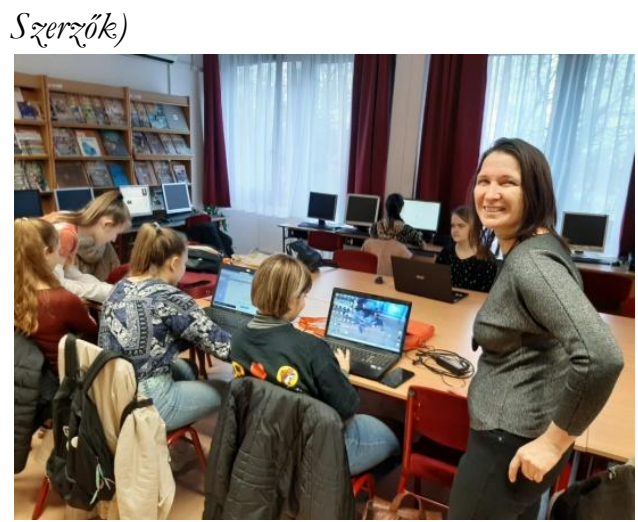

A program keretében tehetséggondozó foglalkozásokon vettek részt a hölgyek, tudományos pályafutást választó kutatónőkkel folytathattak kerekasztal beszélge- tést, nemzetközi konfrencián adhattak elő, illetve ISBN számmal rendelkező, szakmailag lektorált tanulmánykötetben jelent meg első tudományos-ismeretterjesztő stílusban írt tanulmányuk.

\section{A program produktumai}

A „Hölgyek a tudományban” program konkrét eredményeként konferencia prezentációk, tanulmányok, valamint egy szerkesztett kiadvány.

Prezentációk. A programban résztvevő hölgyek előadóként vehettek részt az $\mathrm{V}$. International Interdisciplinary Conference (V. Nemzetközi Interdiszciplináris Konferencia) rendezvényen. Prezentációik címe megtalálhatók a konferencia brosúrában (Mező, 2020).

A konferencia részvétel közvetlen célja az volt, hogy a diákok gyakorlatias bepillantást nyerjenek a témaválasztástól az eredmények prezentációjáig terjedő folyamatba. A hölgyek feladata volt, hogy válasszanak ki egy kutatónőt, aki az érdeklődésüknek megfelelő területen végzett tudományos tevékenységet, s dolgozzák fel életrajtát, majd azt mutassák be egy prezentáció formájában a konferencián. E prezentációval függtek össze a hölgyek által írt tanulmányok.

Tanulmányok. A beválogatott hölgyek példaképként is szolgálni képes kutatónőkről szóló tanulmányokat írtak. A szerzők és az általuk választott kutatónők a következők: 
- Ábrók Anna (2020): Sally Ride;

- Bacsur Tímea (2020): Rita LeviMontalcini;

- Barta Erika Odett (2020): Telkes Mária;

- Barta Zsuzsa (2020): Dorothy Hodgkin;

- Kiss Zsófia (2020): Nicole-Reine Hortense Lepaute;

- Kovács Loretta (2020): Linda Buck;

- Menyhárt Tímea (2020): Artemiszia;

- Parlagi Csenge Panna (2020): Susan Adele Greenfield;

- Rácz Vivien (2020): Alexandriai Hüpatia;

- Szakács Erika Tünde (2020): Rosalind Franklin;

- Tóth Alexandra (2020): Mileva Marić;

- Tóth Virág Rebeka (2020): Barbara McClintock.

E tanulmányok célja egyrészt az volt, hogy a résztvevő hölgyek saját élményt szerezzenek a tanulmányírás alapjaival kapcsolatban. Ennek részeként az irodalmazás, struktúra, fogalmazásmód, irodalomjegyzék és belső hivatkozások rendszere, a megjelentetés folyamata kapcsán nyerhettek gyakorlati tapasztalatokat a diákok.

Másrészt e produktumok a résztvevő hölgyek bibliográfiájának (a legtöbb esetben első!) elemét is jelenti, ami további egyéni ösztöndíjak, pályázatok, felvételi eljárások alkalmával bizonyított teljesítményként támaszthatják alá tehetségükről alkotott véleményt.
A szervezők programról szóló tanulmányai is megjelentek a program keretében (lásd: Mező Katalin, 2019 és jelen tanulmány is ide sorolható).

Könyv. Mező Katalin és Mező Ferenc (2020) szerkesztésében kerül kiadásra a program keretében a „Hölgyek a tudományban” című kiadvány (2. ábra).

2. ábra: „Hölgyek a tudományban” címü kiadvány boritója (Mezoó és Mezó, 2020)

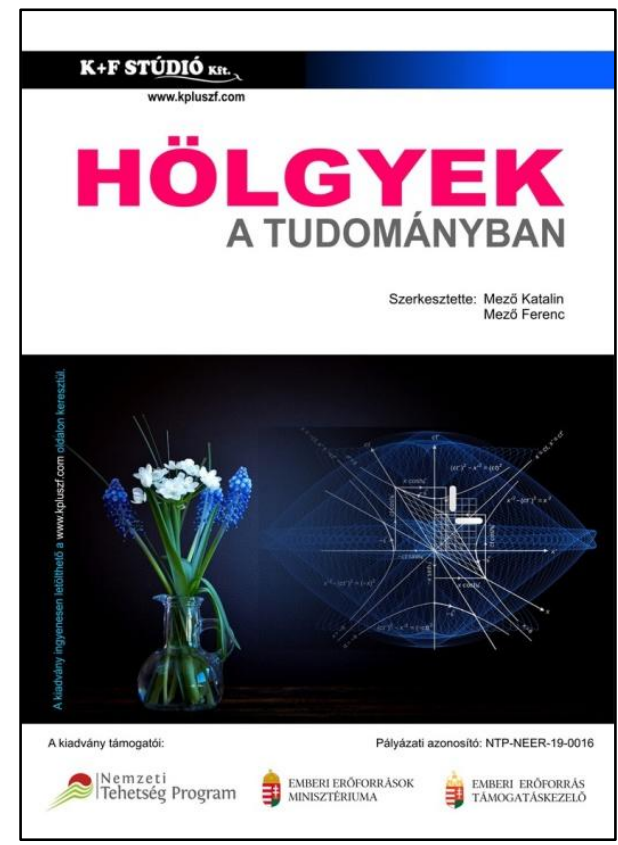

Közösségi médiatartalmak is részét képezik a projektben létrejövő produktumoknak. Ezek elérhetők a $\mathrm{K}+\mathrm{F}$ Stúdió Kft. www.kpluszf.com című weblapjánn keresztül, vagy közvetlenül az alábbi linkek révén: 
- Hölgyek a tudományban (híroldal). Web:https://docs.google.com/forms/ d/e/1FAIpQLSfzV3YjEqF0V7rznhD PJohs7GrB7teZXRZdbSXLD-

QaJx3rrg/viewform

- Hölgyek a tudományban programbemutatás. Web: https://docs.google. com/forms/d/e/1FAIpQLSehv9rOv hPZEbNwxKHA0dBCV2MurMjk08i q6S8aqeyNlQobmA/viewform

\section{Köszönetnyilvánítás}

A „Hölgyek a tudományban” projekt megvalósítása a Nemzeti Tehetség Program támogatásával valósult meg (azonosító: NTP-NEER-19-0016). A támogatást ezúton is köszönjük!

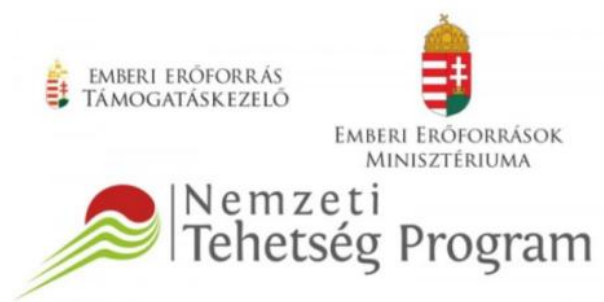

Köszönjük debreceni Medgyessy Ferenc Középiskolában és Mûvészeti Gimnáziumnak, legelsősorban Fekete József igazgatóúrnak és Kiss Papp Csilla igazgatóhelyettes asszonynak önzetlen, tehetségsegítő együttműködésüket! Igazán példaértékű tanulóközpontú tehetséggondozó szemléletük.

\section{Irodalom}

Ábrók Anna (2020): Sally Ride. In: Mező Katalin és Mező Ferenc (szerk.)(2020): Hölgyek a tudományban. K+F Stúdió Kft., Debrecen

Bacsur Tímea (2020): Rita LeviMontalcini. In: Mező Katalin és Mező Ferenc (szerk.)(2020): Hölgyek a tudományban. K+F Stúdió Kft., Debrecen

Barta Erika Odett (2020): Telkes Mária. In: Mező Katalin és Mező Ferenc (szerk.)(2020): Hölgyek a tudományban. K+F Stúdió Kft., Debrecen

Barta Zsuzsa (2020): Dorothy Hodgkin. In: Mező Katalin és Mező Ferenc (szerk.)(2020): Hölgyek a tudományban. $\mathrm{K}+\mathrm{F}$ Stúdió Kft., Debrecen

Hölgyek a tudományban (biroldal). Letöltés: 2020.03.31. Web: https://docs.google. com/forms/d/e/1FAIpQLSfzV3YjE qF0V7rznhDPJohs7GrB7teZXRZdbS XLD-QaJx3rrg/viewform

Hölgyek a tudományban programbemutatás. Letöltés: 2020.03.31. Web: https: //docs.google.com/forms/d/e/1FAI pQLSehv9rOvhPZEbNwxKHA0dBC V2MurMjk08iq6S8aqeyNlQobmA/vie wform

Kiss Zsófia (2020): Nicole-Reine Hortense Lepaute. In: Mező Katalin és Mező Ferenc (szerk.)(2020): Hölgyek a tudományban. K+F Stúdió Kft., Debrecen

Kovács Loretta (2020): Linda Buck. In: Mező Katalin és Mező Ferenc (szerk.)(2020): Hölgyek a tudományban. $\mathrm{K}+\mathrm{F}$ Stúdió Kft., Debrecen 
Menyhárt Tímea (2020): Artemiszia. In: Mező Katalin és Mező Ferenc (szerk.)(2020): Hölgyek a tudományban. K+F Stúdió Kft., Debrecen

Mező Ferenc (szerk.) (2020): V. Nemzetközi Interdiszciplináris Konferencia: brosúra. A szekciók és az elöadók listája. Letöltés: 2020.03.21. Web: https://drive. google.com/file/ d/1djweOM2fqWv48wCR_HZPSdAf P_LWzyqq/view

Mező Katalin (2019): „Hölgyek a tudományban” műhely. Különleges Bánásmód, V. évf. 2019/4., 83-84. Letöltés: 2019.12.28. Web: https://gygyk. unideb.hu/sites/default/files/upload_ documents/kb_2019_4_holgyek_a_tu domanyban.pdf

Mező Katalin és Mező Ferenc (szerk.) (2020): Hölgyek a tudományban. $\mathrm{K}+\mathrm{F}$ Stúdió Kft., Debrecen.
Parlagi Csenge Panna (2020): Susan Adele Greenfield. In: Mező Katalin és Mező Ferenc (szerk.)(2020): Hölgyek a tudományban. K+F Stúdió Kft., Debrecen

Rácz Vivien (2020): Alexandriai Hüpatia. In: Mező Katalin és Mező Ferenc (szerk.)(2020): Hölgyek a tudományban. K+F Stúdió Kft., Debrecen

Szakács Erika Tünde (2020): Rosalind Franklin. In: Mező Katalin és Mező Ferenc (szerk.)(2020): Hölgyek a tudományban. K+F Stúdió Kft., Debrecen

Tóth Alexandra (2020): Mileva Marić. In: Mező Katalin és Mező Ferenc (szerk.)(2020): Hölgyek a tudományban. K+F Stúdió Kft., Debrecen

Tóth Virág Rebeka (2020): Barbara McClintock. In: Mező Katalin és Mező Ferenc (szerk.)(2020): Hölgyek a tudományban. K+F Stúdió Kft., Debrecen 